\title{
CHEMICAL COMPOSITION AND HYDRAULIC PROPERTIES OF INCINERATED WASTEPAPER SLUDGE
}

\author{
Khrystyna Sobol ${ }^{1}$, Serhiy Solodkyy ${ }^{1}$, Nadiya Petrovska1, Sergiy Belov ${ }^{2}$, \\ Oleksii Hunyak $^{1,}{ }^{\otimes}$, Volodymyr Hidei $^{1}$
}

https://doi.org/10.23939/chcht14.04.538

\begin{abstract}
The hydraulic properties of ash from incinerated wastepaper sludge were investigated. It is shown that the phase composition of wastepaper sludge after heat treatment is similar to the classical fired carbonate-clay mixes. The necessity of using the combination of retarding admixtures with different action mechanism is shown. The strength in the initial hardening period is ensured by the formation of AFm-phases and ettringite, and subsequently by increasing the role of $\mathrm{CSH}$.
\end{abstract}

Keywords: wastepaper sludge ash, hydration, binder, retarding admixtures, ettringite.

\section{Introduction}

Nowadays, the development and use of renewable energy sources are the key of sustainable economic development. Alternative non-traditional fuels appear and anthropogenic wastes associated with them require recycling. A significant resource for energy is the use of wastepaper sludge from a paper mill as an alternative green source of thermal energy. As a result of wastepaper recycling, the so-called sludge is formed. It is a dehydrated mass from the mechanical cleaning of paper cardboard production sewages, which consists of cellulose fiber and mineral part. In addition to a cellulose fiber, the organic part of the sludge also includes a certain amount of plastic, wood, process admixtures (starch, surfactants). The inorganic mineral part of the sludge consists of finely ground kaolin and chalk additives, which are used in the production process [1].

In recent years, in many industrialized countries, there has been an increasing interest in the problem of paper waste utilization $[2,3]$. There are currently separate proposals for the use of pre-dried waste in the production

\footnotetext{
${ }^{1}$ Lviv Polytechnic National University,

12, Bandera St., 79013 Lviv, Ukraine

${ }^{2}$ PJSC "Kyiv Cardboard and Paper Mill",

130, Kyivska St., 08703 Obukhiv, Ukraine

凶oleksii.m.guniak@lpnu.ua

(c) Sobol K., Solodkyy S., Petrovska N., Belov S., Hunyak O., Hidei V., 2020
}

of thermal insulation products, ceramic industry, soil stabilization, agriculture and building materials $[4,5]$. However, in Ukraine it is mostly stored in the dumps in the form of wet sludge, causing the environmental pollution problem.

The optimal solution of the wastepaper sludge recycling problem is the complex use of its organic component as a fuel [6] with the subsequent involvement of the generated heat treated remainders in the construction industry [7-9]. An example of a successful solution of the problem of heat-treated anthropogenic waste utilization is the use of wastepaper sludge ash (WSA) in the building materials industry, which still has a huge unrealized utilization potential $[10,11]$. However, properties of WSA and its behaviour strongly depend on the chemical composition, therefore it is essential to provide more data on the evolution of the reaction products [12].

The aim of this work is to study the possibility of obtaining hydraulically active binder systems based on ash and slag waste, which are formed during the incineration of wastepaper sludge as a new type of man-made raw materials. The use of heat-treated wastepaper sludge is a promising trend for fuel and energy savings and reducing the natural resources consumption as well as greenhouse gas emissions [7, 8, 13-16]. This approach complies with the priority principles of uniform and sustainable development of the industry aimed at creating environmentally friendly low energy-intensive technologies.

\section{Experimental}

The raw material was the wastepaper sludge ash (WSA) from PJSC "Kyiv Cardboard and Paper Mill" in the form of pellets mixed with the powder, which is formed after its incineration (Fig. 1). WSA has been ground in a laboratory ball mill for $3 \mathrm{~h}$ to a $5-6 \mathrm{wt} \%$ residue on the sieve No. 008.

The mineralogical composition of WSA and its hydration products were investigated by the X-ray diffraction analysis on a DRON-3.0 diffractometer. The processes occurring during the heat treatment of wastepaper sludge were studied by means of OD- 15000 
thermogravimetric analyser, the weight loss-temperature (TG) and derivative weight loss-temperature (DTG) plots were recorded. The processes of structure formation were studied on pastes at water-to-binder ratio of 0.5 , which hardened at $293 \pm 2 \mathrm{~K}$. The results of WSA chemical analysis are shown in Table 1.

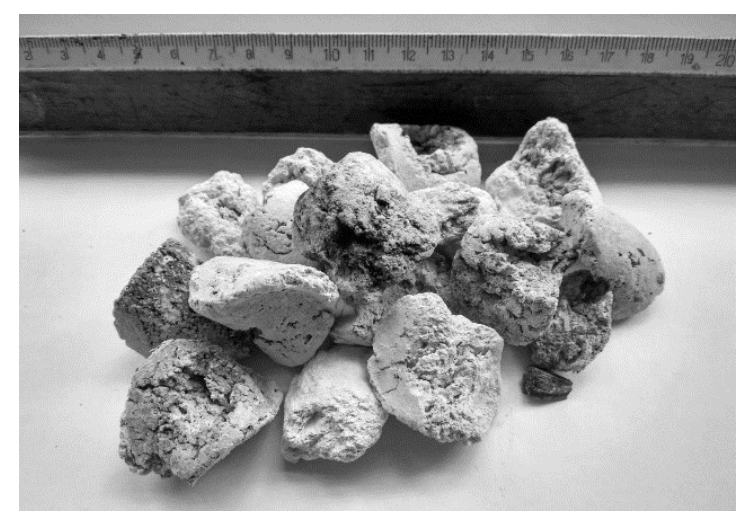

Fig. 1. The appearance of wastepaper sludge ash

Standard consistency pastes with different retarding admixtures were prepared in the EN 196-1 standard mixer [17]. Gypsum $\mathrm{CaSO}_{4} \cdot 2 \mathrm{H}_{2} \mathrm{O}$, boric acid $\mathrm{H}_{3} \mathrm{BO}_{3}$, hydroxycarboxylic acids - citric $\mathrm{C}_{6} \mathrm{H}_{8} \mathrm{O}_{7}$ and tartaric $\mathrm{C}_{4} \mathrm{H}_{6} \mathrm{O}_{6}$ were used as retarding admixtures. Gypsum was ground together with WSA, acids were dissolved in a mixing water in given ratios. Standard consistency, setting time and soundness tests were conducted according to EN 196-3 [18].
Prepared pastes were cast in 30-mm cube moulds, vibrated and demoulded after $24 \mathrm{~h}$. Then specimens were cured in water at $293 \mathrm{~K}$ and compressive strength tests were performed in 1, 3, 7, 14 and 28 days on 3 specimens for each curing period. SEM micrographs were carried out by means of field emission scanning electron microscope HITACHI S-4100.

\section{Results and Discussion}

Studies have shown that in the mineral part of the wastepaper sludge there are calcite $\mathrm{CaCO}_{3}$ - the main rock-forming mineral of chalk $(\mathrm{d} / \mathrm{n}=0.303 ; 0.249 ; 0.207$; $0.209 ; \quad 0.1901 \mathrm{~nm}), \quad$ kaolinite $\quad \mathrm{Al}_{2} \mathrm{O}_{3} \cdot 2 \mathrm{SiO}_{2} \cdot 2 \mathrm{H}_{2} \mathrm{O}$ $(\mathrm{d} / \mathrm{n}=0.715 ; 0.435 ; 0.413 ; 0.385 ; 0.356 ; 0.249 ; 0.231$; $0.228 \mathrm{~nm}$ ), as well as some amounts of quartzite $\mathrm{SiO}_{2}$ impurity $(\mathrm{d} / \mathrm{n}=0.334 \mathrm{~nm})$ (Fig. 2).

The diffraction pattern of WSA (Fig. 3) shows intense lines of $\beta-2 \mathrm{CaO} \cdot \mathrm{SiO}_{2}(\mathrm{~d} / \mathrm{n}=0.227 ; 0.275 ; 0.262$; $0.219 ; 0.1990 \mathrm{~nm}$ ); calcium aluminates $12 \mathrm{CaO} \cdot 7 \mathrm{Al}_{2} \mathrm{O}_{3}$ $(\mathrm{d} / \mathrm{n}=0.492 ; 0.270 ; 0.245 ; 0.219 \mathrm{~nm})$, and $3 \mathrm{CaO} \cdot \mathrm{SiO}_{3}(\mathrm{~d} / \mathrm{n}$ $=0.423 ; 0.277 ; 0.270 ; 0.1901 ; 0.1554 \mathrm{~nm})$, as well as gehlenite $2 \mathrm{CaO} \cdot \mathrm{Al}_{2} \mathrm{O}_{3} \cdot \mathrm{SiO}_{2}(\mathrm{~d} / \mathrm{n}=0.370 ; 0.286 ; 0.245$; $0.240 ; 0.228 ; 0.176 \mathrm{~nm}$ ). In addition, the following minerals are present in small amounts: undiluted calcite $\mathrm{CaCO}_{3}(\mathrm{~d} / \mathrm{n}=0.303 ; 0.228 ; 0.209 \mathrm{~nm})$, free lime $\mathrm{CaO}$ $(\mathrm{d} / \mathrm{n}=0.240 ; 0.1698 \mathrm{~nm})$ and the product of its hydration $\mathrm{Ca}(\mathrm{OH})_{2}$, which was formed as a result of wet environment storage $(\mathrm{d} / \mathrm{n}=0.492 ; 0.262 \mathrm{~nm})$, as well as $\mathrm{SiO}_{2}(\mathrm{~d} / \mathrm{n}=0.423 ; 0.334 ; 0.228 \mathrm{~nm})$.

Table 1

Chemical composition of WSA, wt \%

\begin{tabular}{|c|c|c|c|c|c|c|}
\hline $\mathrm{SiO}_{2}$ & $\mathrm{Al}_{2} \mathrm{O}_{3}$ & $\mathrm{Fe}_{2} \mathrm{O}_{3}$ & $\mathrm{CaO}$ & $\mathrm{MgO}$ & $\mathrm{SO}_{3}$ & $\mathrm{LOI}$ \\
\hline 26.44 & 15.36 & 1.16 & 49.84 & 2.16 & 0.45 & 3.13 \\
\hline
\end{tabular}

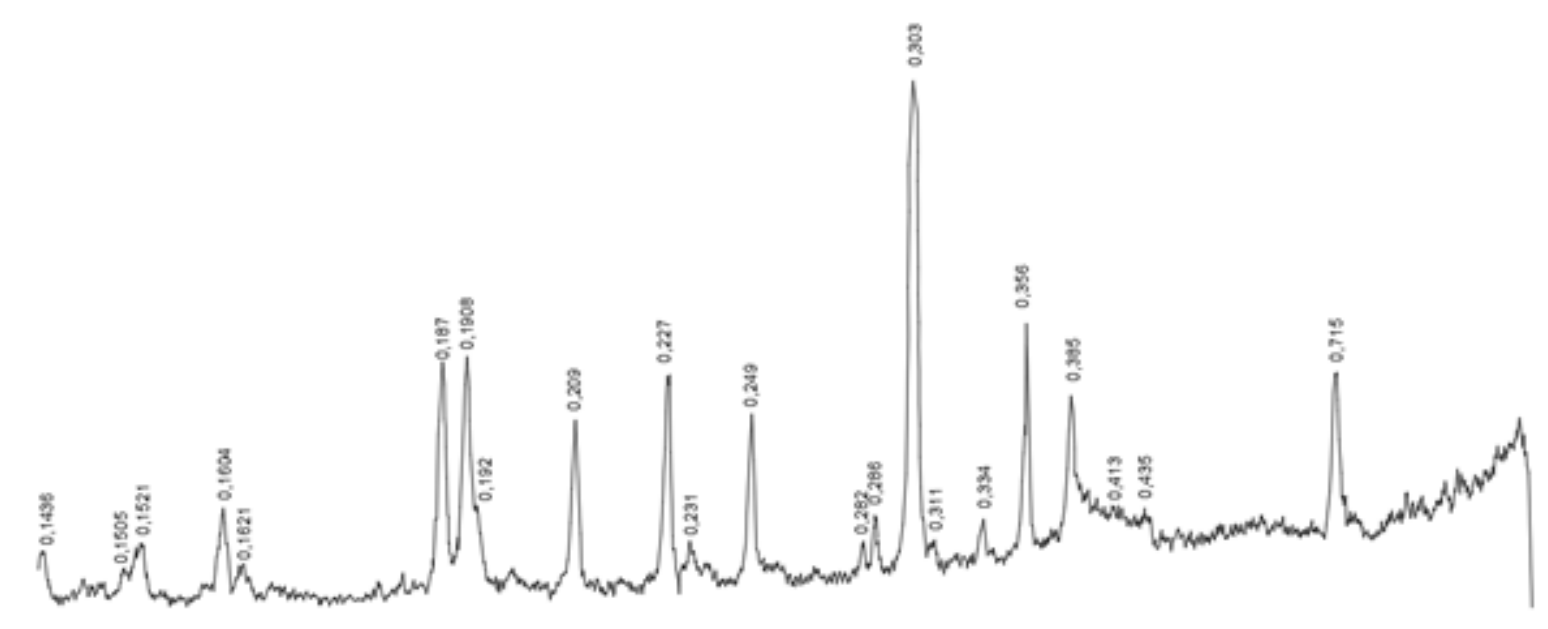

Fig. 2. XRD pattern of wastepaper sludge 


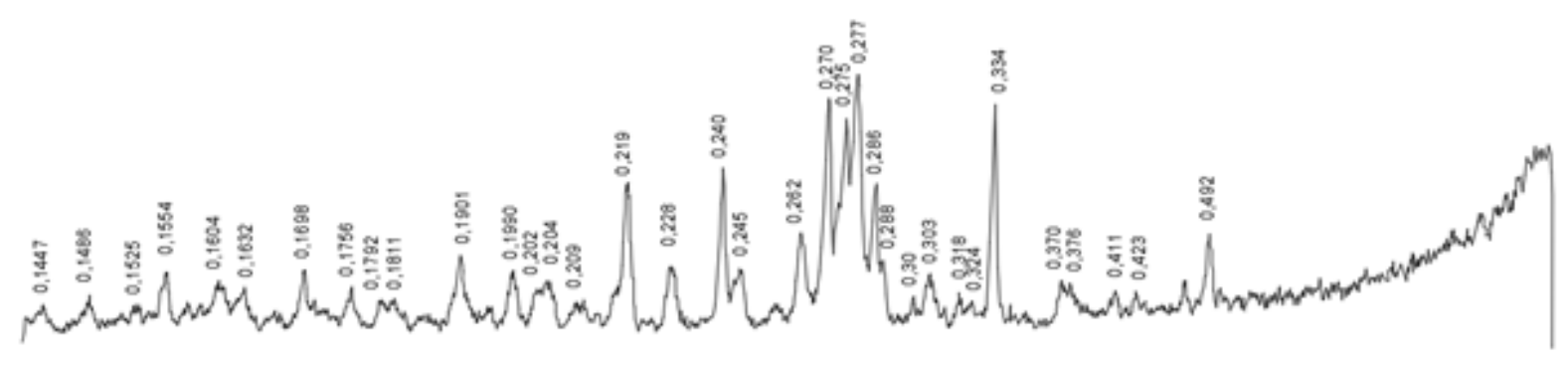

Fig. 3. XRD pattern of wastepaper sludge ash

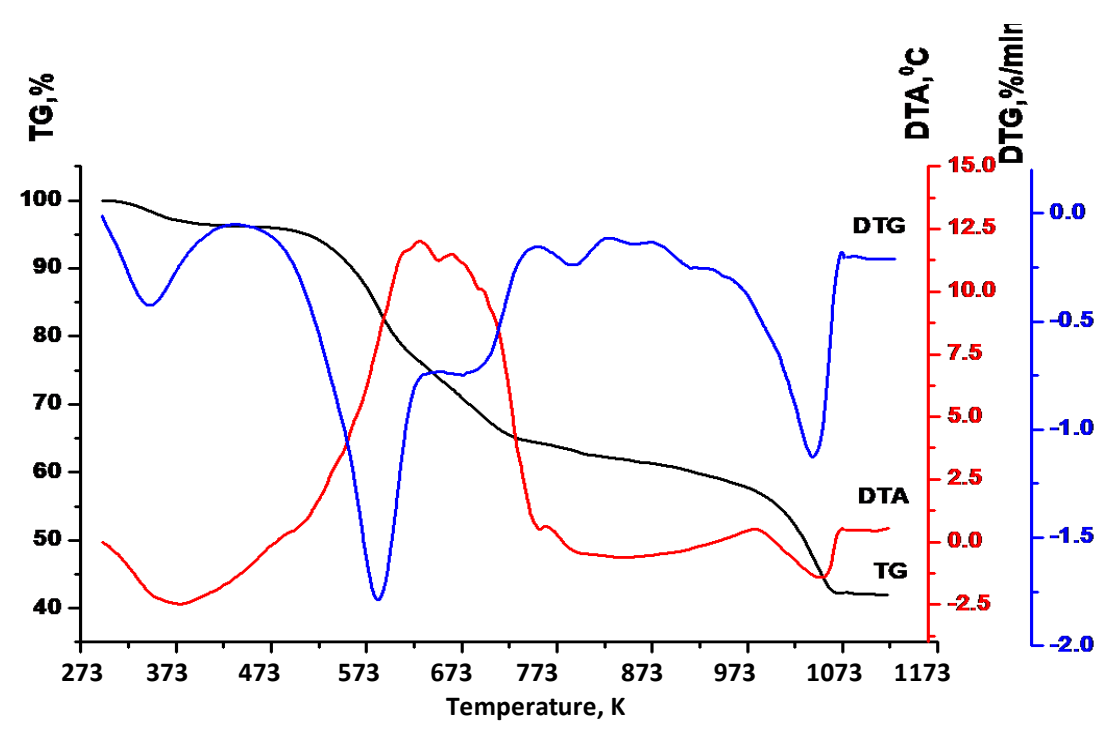

Fig. 4. DTA/TG/DTG curves of wastepaper sludge

DTA analysis of wastepaper sludge (Fig. 4) is complicated by the imposition of two simultaneously occurring processes - the combustion of the organic component and the firing of the mineral part of the sludge [11]. Endothermic effect at $373 \mathrm{~K}$ is associated with the removal of physically bound water. It immediately turns into a powerful exothermic effect with a maximum at $633 \mathrm{~K}$, which is formed after the organic component burning. This effect hides the process of stepwise dehydration of kaolinite and therefore only a small endothermic effect at $813 \mathrm{~K}$ characterizes the removal of chemically bound structural water and kaolinite $\mathrm{Al}_{2} \mathrm{O}_{3} \cdot 2 \mathrm{SiO}_{2} \cdot 2 \mathrm{H}_{2} \mathrm{O}$ dehydroxylation with the formation of metastable amorphized metakaolinite [19]:

$$
\mathrm{Al}_{2} \mathrm{O}_{3} \cdot 2 \mathrm{SiO}_{2} \cdot 2 \mathrm{H}_{2} \mathrm{O} \rightarrow \mathrm{Al}_{2} \mathrm{O}_{3} \cdot 2 \mathrm{SiO}_{2}+\mathrm{H}_{2} \mathrm{O}
$$

Sludge decarbonation process begins at $873 \mathrm{~K}$ as a result of thermochemical dissociation of chalk by the interaction between calcite and metakaolinite, which are highly reactive:

$$
\rightarrow \underset{\mathrm{CaCO}}{\mathrm{CaCO}_{3}+\mathrm{Al}_{2} \mathrm{O}_{3} \cdot 2 \mathrm{SiO}_{2} \rightarrow} \rightarrow \underset{\mathrm{CaO} \cdot \mathrm{SiO}_{2}+n \mathrm{CaO} \cdot \mathrm{Al}_{2} \mathrm{O}_{3}+\mathrm{CO}_{2}}{ }
$$

The endothermic effect with the maximum at $1043 \mathrm{~K}$ characterizes the thermal dissociation of calcite:

$$
\mathrm{CaCO}_{3} \rightarrow \mathrm{CaO}+\mathrm{CO}_{2}
$$

According to the thermodynamically determined sequence the following minerals are formed: in the system $\mathrm{CaO}-\mathrm{SiO}_{2}$ - primary product of $2 \mathrm{CaO} \cdot \mathrm{SiO}_{2}$, calcium monoaluminate $\mathrm{CaO} \cdot \mathrm{Al}_{2} \mathrm{O}_{3}$ - in the system $\mathrm{CaO}-\mathrm{Al}_{2} \mathrm{O}_{3}$, gelenite $2 \mathrm{CaO} \cdot \mathrm{Al}_{2} \mathrm{O}_{3} \cdot \mathrm{SiO}_{2}$ - in the system $\mathrm{CaO}-\mathrm{Al}_{2} \mathrm{O}_{3}$ $\mathrm{SiO}_{2}[20,21]$.

Dicalcium silicate $\beta-2 \mathrm{CaO} \cdot \mathrm{SiO}_{2}$ begins to form at the temperature of $873 \mathrm{~K}$, but with a sufficient speed this process occurs at higher temperatures. It was established [21], that $\beta-\mathrm{C}_{2} \mathrm{~S}$ obtained at the temperature below 1173$1373 \mathrm{~K}$ does not convert to hydraulically inert $\gamma-\mathrm{C}_{2} \mathrm{~S}$, and its strength characteristics are much higher than those obtained at a temperature of $1673-1723 \mathrm{~K}$ in Portland cement clinker.

Calcium monoaluminate $\mathrm{CaO} \cdot \mathrm{Al}_{2} \mathrm{O}_{3}$ already forms at $973 \mathrm{~K}$. However, due to the fact that the mineral part of the wastepaper sludge contains insufficient amount of $\mathrm{Al}_{2} \mathrm{O}_{3}$, the saturation of $\mathrm{CaO} \cdot \mathrm{Al}_{2} \mathrm{O}_{3}$ is reduced to more basic aluminates - first to $12 \mathrm{CaO} \cdot 7 \mathrm{Al}_{2} \mathrm{O}_{3}$, and then to 
$3 \mathrm{CaO} \cdot \mathrm{Al}_{2} \mathrm{O}_{3}$. The probability of $3 \mathrm{CaO} \cdot \mathrm{Al}_{2} \mathrm{O}_{3}$ formation at $1123 \mathrm{~K}$ has been confirmed [22].

Thus, it is established on the basis of the obtained results that the processes of phase formation in the mineral part of the wastepaper sludge during its combustion are similar to the classic firing schemes of carbonate-clay mixtures. They include kaolin dehydration, metakaolinite $\mathrm{Al}_{2} \mathrm{O}_{3} \cdot 2 \mathrm{SiO}_{2}$ formation, chalk decarbonation, the formation of primary products after the reaction between $\mathrm{CaO}$ and metakaolinite $\mathrm{Al}_{2} \mathrm{O}_{3} \cdot 2 \mathrm{SiO}_{2}$, lime saturation of lowbasic interaction products to more basic ones. A thermally activated product consisting of $\beta-2 \mathrm{CaO} \cdot \mathrm{SiO}_{2}$, $12 \mathrm{CaO} \cdot 7 \mathrm{Al}_{2} \mathrm{O}_{3}, 3 \mathrm{CaO} \cdot \mathrm{Al}_{2} \mathrm{O}$ and $2 \mathrm{CaO} \cdot \mathrm{Al}_{2} \mathrm{O}_{3} \cdot \mathrm{SiO}_{2}$ (Fig. 5) is obtained because of these processes.

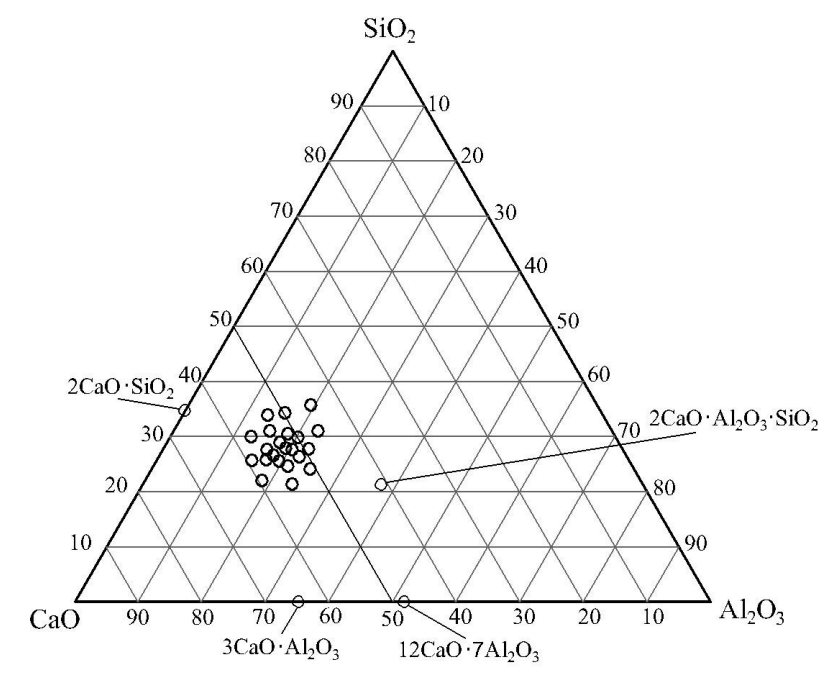

Fig. 5. Phase diagram of the ternary $\mathrm{CaO} \cdot \mathrm{Al}_{2} \mathrm{O}_{3} \cdot \mathrm{SiO}_{2}$ system relative to the WSA composition

It is known that the preliminary evaluation of the binder properties of calcium-containing systems is carried out using the hydraulic modulus [20].

$$
M_{H}=\% \mathrm{SiO}_{2}+\% \mathrm{Al}_{2} \mathrm{O}_{3}+\% \mathrm{Fe}_{2} \mathrm{O}_{3}
$$

According to results of chemical analysis (Table 1), calculated value of $M_{H}$ is 1.16 . Therefore, the studied WSA can be attributed to Roman cement due to its properties, which occupies an intermediate position between hydraulic lime and Portland cement [20]. In addition to the hydraulic modulus, the temperature and firing mode are crucial to form the hydraulically active phases. The reactivity of the raw material components in the mixture and the presence of impurities in it are equally important [21]. Unlike to Roman cement, significant amounts of calcium aluminates are present in the studied WSA, in particular highly basic $3 \mathrm{CaO} \cdot \mathrm{Al}_{2} \mathrm{O}_{3}$.

It is established that the peculiarity of the obtained product is an extremely active reaction with water, which is accompanied by heat release and increase of the paste temperature up to $323-333 \mathrm{~K}$, as well as the partial water evaporation and rapid setting. This is due to the hydration reaction of calcium aluminates $12 \mathrm{CaO} \cdot 7 \mathrm{Al}_{2} \mathrm{O}_{3}$ and $3 \mathrm{CaO} \cdot \mathrm{Al}_{2} \mathrm{O}_{3}$, which are present in WSA composition. They are highly exothermic and are characterized by the active structure formation in the first minutes after mixing with water $[22,20]$.

In such cases, rapid and uniform heat removal or the use of retarding and plasticizing admixtures can provide the necessary conditions for proper hydration. In order to slow down the early structure formation processes, a classical retarding additive was used in the form of natural gypsum stone $\left(\mathrm{CaSO}_{4} \cdot 2 \mathrm{H}_{2} \mathrm{O}\right)$ which was added in the amount of $5-20 \mathrm{wt} \%$ to the test material by intergrinding, as well as oxycarboxylic acids - citric $\mathrm{C}_{6} \mathrm{H}_{8} \mathrm{O}_{7}$ and tartaric $\mathrm{C}_{4} \mathrm{H}_{6} \mathrm{O}_{6}$.

The use of gypsum is a well-known method to adjust the setting time in the $\mathrm{CaO}-\mathrm{Al}_{2} \mathrm{O}_{3}-\mathrm{SiO}_{2}-\mathrm{H}_{2} \mathrm{O}$ systems [23]. The retarding effect is based on the formation of fine crystalline ettringite $3 \mathrm{CaO} \cdot \mathrm{AlO}_{3} \cdot 3 \mathrm{CaSO}_{4} \cdot 31 \mathrm{H}_{2} \mathrm{O}$ on the surface of primary metastable calcium aluminate hydrates. It acts as a passive blocking layer without negative effect on the paste flowability. But over time ettringite recrystallizes into prismatic needle-like crystals, which tend to coalesce during setting and later strengthen the structure of hardened binder $[20,24,25]$.

The results show that 5-7 wt \% addition of gypsum is insufficient and does not significantly affect the WSA setting time. Increasing the gypsum amount to $12 \mathrm{wt} \%$ allows to delay the initial setting up to $10 \mathrm{~min}$. A considerable prolongation of setting time (up to 35 and $50 \mathrm{~min}$ for initial and final, respectively) was achieved with $20 \mathrm{wt} \%$ of gypsum addition (Fig. 6).

It was found that increasing the gypsum additive content up to $20 \mathrm{wt} \%$ negatively affects the strength of the binder (Table 2). This is due to the formation of ettringite $3 \mathrm{CaO} \cdot \mathrm{Al}_{2} \mathrm{O}_{3} \cdot 3 \mathrm{CaSO}_{4} \cdot 31 \mathrm{H}_{2} \mathrm{O}$ in the excess amount which causes the destructive processes in the hardening system [15].

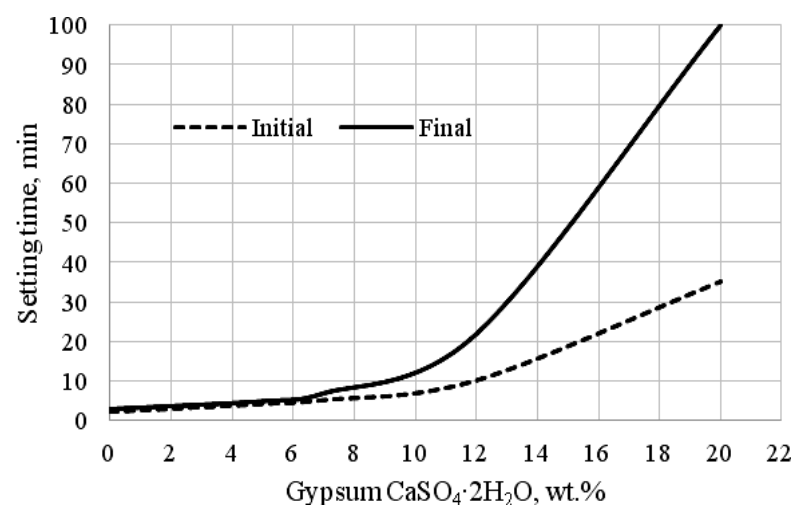

Fig. 6. The effect of gypsum $\mathrm{CaSO}_{4} \cdot 2 \mathrm{H}_{2} \mathrm{O}$ on the WSA paste setting time 
The effect of chemical admixtures on the binding properties of WSA

\begin{tabular}{|c|c|c|c|c|c|c|c|c|c|c|c|}
\hline \multirow{3}{*}{$\begin{array}{l}\text { Mix. } \\
\text { No }\end{array}$} & \multicolumn{2}{|c|}{ Admixture } & \multirow{3}{*}{$\mathrm{W} / \mathrm{B}$ ratio } & \multirow{2}{*}{\multicolumn{2}{|c|}{ Setting time, hour:minute }} & \multirow{3}{*}{ Soundness } & \multirow{2}{*}{\multicolumn{5}{|c|}{$\begin{array}{c}\text { Compressive strength, } \mathrm{MPa}, \\
\text { at the age, days }\end{array}$}} \\
\hline & \multirow{2}{*}{ Identification } & \multirow{2}{*}{$\begin{array}{l}\text { Amount, } \\
\text { wt \% }\end{array}$} & & & & & & & & & \\
\hline & & & & initial & final & & 1 & 3 & 7 & 14 & 28 \\
\hline 1 & $\mathrm{CaSO}_{4} 2 \mathrm{H}_{2} \mathrm{O}$ & 20.0 & 0.44 & $0: 35$ & $1: 40$ & No & 0.2 & 0.3 & 0.8 & 0.8 & 0.6 \\
\hline 2 & $\begin{array}{c}\mathrm{CaSO}_{4} \cdot 2 \mathrm{H}_{2} \mathrm{O}+ \\
\mathrm{C}_{3} \mathrm{BO}_{3}\end{array}$ & $\begin{array}{l}7.0 \\
1.0\end{array}$ & 0.43 & $0: 40$ & $1: 35$ & No & - & - & 0.1 & 0.2 & 0.4 \\
\hline 3 & $\begin{array}{c}\mathrm{CaSO}_{4} \cdot 2 \mathrm{H}_{2} \mathrm{O}+ \\
\mathrm{C}_{6} \mathrm{H}_{8} \mathrm{O}_{7}\end{array}$ & $\begin{array}{l}7.0 \\
1.0\end{array}$ & 0.41 & $0: 30$ & $1: 25$ & No & - & - & 0.2 & 0.3 & 0.6 \\
\hline 4 & $\begin{array}{c}\mathrm{CaSO}_{4} \cdot 2 \mathrm{H}_{2} \mathrm{O}+ \\
\mathrm{C}_{4} \mathrm{H}_{6} \mathrm{O}_{6}\end{array}$ & $\begin{array}{l}7.0 \\
0.5\end{array}$ & 0.40 & $0: 15$ & $0: 32$ & Yes & 6.2 & 7.1 & 9.0 & 9.9 & 11.8 \\
\hline 5 & $\begin{array}{c}\mathrm{CaSO}_{4} \cdot 2 \mathrm{H}_{2} \mathrm{O}+ \\
\mathrm{C}_{4} \mathrm{H}_{6} \mathrm{O}_{6}\end{array}$ & $\begin{array}{l}7.0 \\
1.0\end{array}$ & 0.38 & $0: 45$ & $1: 05$ & Yes & 7.3 & 8.2 & 9.3 & 10.6 & 13.5 \\
\hline
\end{tabular}

Further study was aimed at achieving the double effect: extending setting time while maintaining the positive role of gypsum in the processes of early structure formation.

For this purpose, complex additives of retarding action were investigated, which included $7 \mathrm{wt} \%$ of $\mathrm{CaSO}_{4} \cdot 2 \mathrm{H}_{2} \mathrm{O}$ and $0.5-1.0 \mathrm{wt} \%$ of boric, citric and tartaric acids, which were added with mixing water. As can be seen from Table 2, binders that contained gypsum together with $1 \mathrm{wt} \%$ of boric and $1 \mathrm{wt} \%$ of citric acid showed a good retarding effect. But their retardation action was not limited to the hardening process, and continued with the subsequent hydration of the binders. Therefore, mixtures 2 and 3 had the lowest strength among all the investigated compounds. The retardation effect of the complex additive (gypsum and tartaric acid) is limited only by the setting time. It was found that $0.5 \mathrm{wt} \%$ addition of tartaric acid shortens the initial setting time to $15 \mathrm{~min}$ and the final setting time up to $32 \mathrm{~min}$. When $1.0 \mathrm{wt} \%$ of tartaric acid is added to the mixture, initial and final setting time retards to 45 and $65 \mathrm{~min}$, respectively (Table 2). Synergistic combination of components individual properties and their specific action mechanism provide the effectiveness of the complex admixture.

The retarding action of tartaric acid was achieved by its adsorption on the non-hydrated binder surface and primary hydration phases as well as by the formation of chelate complexes between the hydroxyl and carboxyl groups of the admixture and $\mathrm{Al}^{3-}$ ions. The formed complexes are stable enough to retard the hydration reaction due to the slow dissolution of binder grains and the increase in the diffusion resistance. The prolongation of setting time is observed due to the diffusion through the layer of hexagonal calcium hydroaluminates $4 \mathrm{CO} \cdot \mathrm{Al}_{2} \mathrm{O}_{3} \cdot 13 \mathrm{H}_{2} \mathrm{O}$, which is the primary phase in the hydration of high-basic calcium aluminates. The forementioned phenomena are a limiting stage in the development of early structure formation processes [24]. Over time, as the hydration of aluminates is activated, the previously considered retardation mechanism of gypsum takes place. As a result, the addition of a complex admixture $(7.0 \mathrm{wt} \%$ of gypsum and $1.0 \mathrm{wt} \%$ of tartaric acid) to the WSA paste allows to obtain an effective setting time retardation. There is a positive effect of this admixtures on the further development of structure formation processes, which is confirmed by a uniform increase in the samples strength (Table 2).

The diffraction pattern analysis of hydrated WSA (Fig. 7) showed the presence of stable hexagonal AFmphases, which do not transform into the cube-shaped aluminate hydrates over time.

The main hydration product of WSA is the hexagonal calcium aluminate hydrate in the form of hydrocalumite $\left[\mathrm{Ca}_{2} \mathrm{Al}(\mathrm{OH})_{6}\right] \cdot\left[(\mathrm{OH})_{2}\left(\mathrm{CO}_{3}\right)\right] \cdot 6 \mathrm{H}_{2} \mathrm{O} \quad(\mathrm{d} / \mathrm{n}=$ $=0.820 ; 0.386 ; 0.288 ; 0.245 \mathrm{~nm})$. Its stability in the studied system is related to a certain amount of $\mathrm{CO}_{3}{ }^{2-}$ ions, which are present in the crystalline lattice [22]. The formation of AFm-type carbon-containing calcium aluminate hydrate can be explained by the presence of highly reactive $\mathrm{CaCO}_{3}$ $(\mathrm{d} / \mathrm{n}=0.303 ; 0.228 ; 0.187 \mathrm{~nm})$ (Fig.7 ) in the hardening system. As a result, hexagonal aluminate hydrate does not convert into cubic-shaped ones and there is no associated strength reduction in a hardened paste. In addition, gelenite interacts with water producing hydrogelenite $\left[\mathrm{Ca}_{2} \mathrm{Al}(\mathrm{OH})_{6}\right] \cdot\left[\mathrm{AlSiO}_{3}(\mathrm{OH})_{2} \cdot 4 \mathrm{H} 2 \mathrm{O}\right]$, which is also a stable and structurally active AFm-phase [2].

Ettringite $(\mathrm{d} / \mathrm{n}=0.97 ; 0.56 ; 0.467 ; 0.386 ; 0.255 \mathrm{~nm})$ (Fig.7) is the main hydration phase which provides the retardation of hardening process and the early strength development of the WSA-based binder. It may also include some carbonate ions

$\left[\mathrm{Ca}_{2} \mathrm{Al}(\mathrm{OH})_{6} \cdot 12 \mathrm{H}_{2} \mathrm{O}\right]_{2} \cdot\left[\left(\mathrm{SO}_{4}\right)_{3}\left(\mathrm{CO}_{3}\right)_{3} \cdot 2 \mathrm{H}_{2} \mathrm{O}[15,24]\right.$

High hydration degree of $3 \mathrm{CaO} \cdot \mathrm{Al}_{2} \mathrm{O}_{3}$ and $12 \mathrm{CaO} \cdot 7 \mathrm{Al}_{2} \mathrm{O}_{3}$ in the waste composition is indicated by the absence of their characteristic maximum on the diffraction plot (Fig. 7). There is also a decrease in the pattern intensity of the $\beta-\mathrm{C}_{2} \mathrm{~S}(\mathrm{~d} / \mathrm{n}=0.277 ; 0.275 ; 0.262 \mathrm{~nm})$, which hydrates slowly and provides durability at later ages. 



Fig. 7. Diffraction plots of hydrated WSA containing $7 \mathrm{wt} \%$ of $\mathrm{CaSO}_{4} \cdot 2 \mathrm{H}_{2} \mathrm{O}$ and $1.0 \mathrm{wt} \%$ of $\mathrm{C}_{4} \mathrm{H}_{6} \mathrm{O}_{6}$ after 7(1) and 28(2) days of hardening

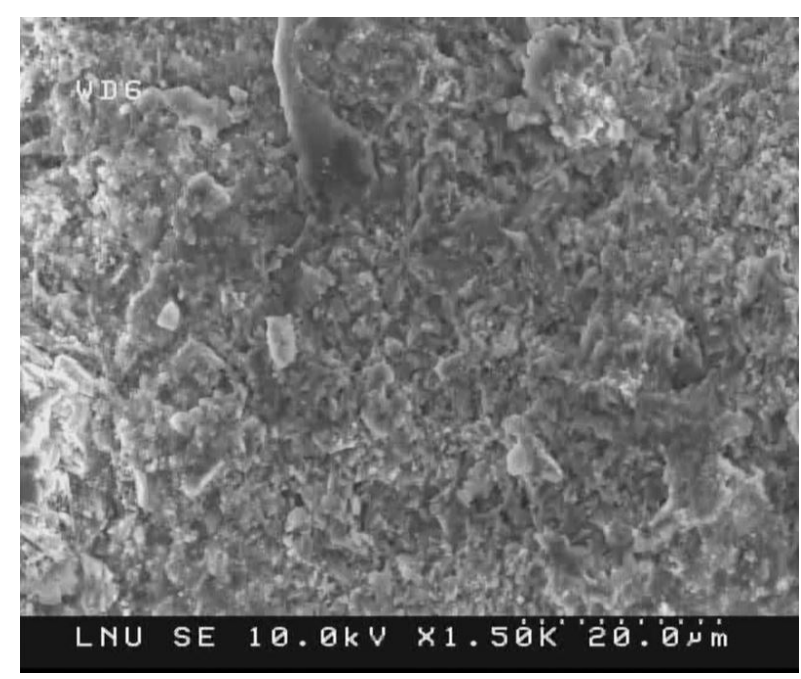

a)

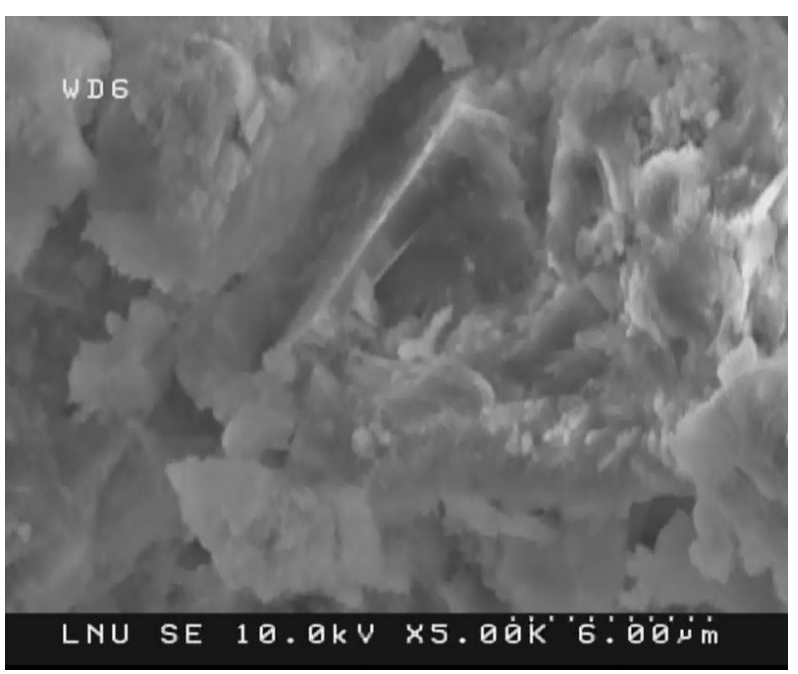

b)

Fig. 8. SEM images of the hydrated WSA

The SEM images of the studied samples show a large number of small coalescing pores. It should be noted that there is a number of tightly packed hexagonal crystalline plates that can be attributed to hydrocalumite $\left[\mathrm{Ca}_{2} \mathrm{Al}(\mathrm{OH})_{6}\right] \cdot\left[(\mathrm{OH})_{2}\left(\mathrm{CO}_{3}\right)\right] \cdot 6 \mathrm{H}_{2} \mathrm{O}$ (Fig. $8 \mathrm{a}$ ) and hydrogelenite $\left[\mathrm{Ca}_{2} \mathrm{Al}(\mathrm{OH})_{6}\right] \cdot\left[\mathrm{AISiO}_{3}(\mathrm{OH})_{2} \cdot 4 \mathrm{H}_{2} \mathrm{O}\right]$. In some places crystals of carbonate-containing ettringite $\left[\mathrm{Ca}_{2} \mathrm{Al}(\mathrm{OH})_{6} \cdot 12 \mathrm{H}_{2} \mathrm{O}\right]_{2} \cdot\left[\left(\mathrm{SO}_{4}\right)_{3}\left(\mathrm{CO}_{3}\right)_{3} \cdot 2 \mathrm{H}_{2} \mathrm{O}\right.$ (Fig. 8b) are observed.

\section{Conclusions}

It was found that the incinerated wastepaper sludge is a thermally activated hydraulically active product. Using a set of physicochemical analysis methods it was found that the peculiarity of their mineralogical composition is the presence of highly basic calcium aluminates $3 \mathrm{CaO} \cdot \mathrm{Al}_{2} \mathrm{O}_{3}$ and $12 \mathrm{CaO} \cdot 7 \mathrm{Al}_{2} \mathrm{O}_{3}$. It is shown that the effective hydration and structure formation of 
wastepaper sludge ash are impossible without retarding additions, in particular the combination of gypsum $\mathrm{CaSO}_{4} \cdot 2 \mathrm{H}_{2} \mathrm{O} \quad(7 \mathrm{wt} \%)$ and tartaric acid $\mathrm{C}_{4} \mathrm{H}_{6} \mathrm{O}_{6}$ $(1.0 \mathrm{wt} \%)$. The strength of the samples in the initial hardening period is ensured by the formation of conversion-stable carbon-containing hexagonal AFmphases and ettringite. Subsequently, the strength of samples is provided by calcium silicate hydrates.

The use of modifying additions with different action mechanism in the composition wastepaper sludge ash provides the formation of hardened cement paste with specified properties and allows to expand the areas of their practical application as a supplementary cementitious material in blended Portland cement, hydraulic road binders and soil stabilization, as a part of multicomponent dry building mixtures, in mortars, etc.

\section{References}

[1] https://www.papir.kiev.ua/wp-

content/uploads/2019/06/\%D0\%92\%D0\%B8\%D1\%81\%D0\%BD $\%$ $\mathrm{D} 0 \% \mathrm{BE} \% \mathrm{D} 0 \% \mathrm{~B} 2 \% \mathrm{D} 0 \% \mathrm{BE} \% \mathrm{D} 0 \% \mathrm{BA}-$

$\% \mathrm{D} 1 \% 81 \% \mathrm{D} 0 \% \mathrm{BA} \% \mathrm{D} 0 \% \mathrm{BE} \% \mathrm{D} 0 \% \mathrm{BF} 2019$.pdf.

[2] Monte M., Fuente E., Blanco A., Negro C.: Waste Manage., 2009, 29, 293. https://doi.org/10.1016/j.wasman.2008.02.002

[3] Bajpai P.: Management of Pulp and Paper Mill Waste. Springer Int. Publ. 2015.

[4] Cusido J., Cremandes L., Suricano C., Devant M.: Appl. Clay Sci., 2015, 108, 191. https://doi.org/10.1016/j.clay.2015.02.027

[5] Ahmadi B., Al-Khaja W.: Resour., Conserv. Recy., 2001, 32, 105. https://doi.org/10.1016/S0921-3449(01)00051-9

[6] Yu J., Kim S., Lee J., Lee K.: Energy, 2002, 27, 457.

https://doi.org/10.1016/S0360-5442(01)00097-4

[7] Frias M., Rodriguez O., Sanchez de Rojas M.: Constr. Build.

Mater., 2015, 74, 37.

https://doi.org/10.1016/j.conbuildmat.2014.10.007

[8] Segui P., Aubert J., Husson B., Measson M.: Appl. Clay Sci., 2015, 57, 79. https://doi.org/10.1016/j.clay.2012.01.007

[9] Jan S., Sagoe-Crentsil K., Shapiro G.: J. Environ. Manage., 2011, 92, 2085. https://doi.org/10.1016/j.jenvman.2011.03.028

[10] Krivenko P., Pushkareva E., Gots V., Kovalchuk G.: Tsementy i Betonu na Osnove Toplivnych Zol i Shlakov. Express-Poligraf, Kyiv 2012.

[11] Kinuthia J.: Wastepaper Sludge Ash [in:] Siddique R., Cachim P. (Eds.), Waste and Supplementary Cementitious Materials in Concrete. Woodhead Publ. 2018, 289-321.

[12] Gluth G., Lehmann C., Rübner K., Kühne H.: Cem. Concr. Compos., 2014, 45, 82.

https://doi.org/10.1016/j.cemconcomp.2013.09.009

[13] Ferreiro S., Frias V., Vigil de la Villa R., Sanchez de Rojas M.: Cem. Concr. Compos., 2013, 37, 136.

https://doi.org/10.1016/j.cemconcomp.2012.11.005

[14] Frias M., Garcia R., Vigil R., Ferreiro S.: Appl. Clay Sci., 2001, 42, 189. https://doi.org/10.1016/j.clay.2008.01.013
[15] Markiv T., Sobol K., Petrovska N., Hunyak O.: The Effect of Porous Pozzolanic Polydisperse Mineral Components on Properties of Concrete [in]: International Conference Current Issues of Civil and Environmental Engineering. Springer, Cham., Lviv-KošiceRzeszów 2019, 275-282.

[16] Sanytsky M., Sobol K., Shcturmay M., Khymko O.: Chem. Chem. Technol., 2011, 5, 227.

https://doi.org/10.23939/chcht05.02.227

[17] BS EN 196-1, Methods of Testing cement: Part 1.

Determination of Strength, BSI, European Committee for Standardization (CEN), Brussels 1995.

[18] BS EN 196-3, Methods of Testing Cement: Part 3.

Determination of Setting Time and Soundness, BSI, European

Committee for Standardization (CEN), Brussels 1995.

[19] Jang H., Lim Y. et al.: Constr. Build. Mater., 2018, 166, 257.

https://doi.org/10.1016/j.conbuildmat.2018.01.119

[20] Runova R., Dvorkin L., Dvorkin O., Nosovskiy Yu.: Vyazuchi Rechovyny. Osnova, Kyiv 2012.

[21] Pashchenko O., Serbin V., Starchevska O.: Vyazhuchi Materialy. Vyshcha shkola, Kyiv 1995.

[22] Taylor H.: Khimia Tsementa. Mir, Moskva 1996.

[23] Yakymechko Y., Chekansky B.: Chem. Chem. Technol., 2017, 11, 93. https://doi.org/10.23939/chcht11.01.093

[24] Pashchenko A.: Theoria Tsementa. Budivelnyk, Kyiv 1991.

[25] Sanytsky M., Kropyvnytska T., Fischer H., Kondratieva N.: Chem. Chem. Technol., 2019, 13, 495.

https://doi.org/10.23939/chcht13.04.495

Received: May 19, 2019 / Revised: June 02, 2019 / Accepted: August 2019

\section{ДОСЛІДЖЕННЯ СКЛАДУ \\ ТА ГІДРАВЛІЧНИХ ВЛАСТИВОСТЕЙ ТЕРМОАКТИВОВАНИХ ВІДХОДІВ ПАПЕРОВОГО ВИРОБНИЦТВА}

Анотація. Досліджені гідравлічні властивості відходів від спалювання макулатурного скопу - перспективного альтернативного біологічного джерела теплової енергї для відновлювальної енергетики. Показано, що формування фазового складу $в$ мінеральній частині макулатурного скопу при термообробленні відбувається подібно до класичних схем випалу карбонатно-глинистих сумішей з утворенням $\beta-C_{2} S, C_{12} A, C_{3} A$ та $C_{2} A S$. Встановлено, що особливістю досліджуваних відходів є активна взаємодія з водою, інтенсивне тепловиділення та короткі терміни тужавіння. Показана необхідність використання комбінованих сповільнюючих додатків з різним механізмом дії. Міиність в початковий період тверднення забезпечується утворенням конверсійно-стабільних карбонатмістких гексагональних AFm- фаз та етрингіту, $а$ в подальшому внаслідок збільшення ролі гідросилікатів кальиію. Встановлено, щзо золо-илакові відходи від спалювання макулатурного скопу мають в 'яжучі властивості, утворюють тверднучі системи $i$ можуть використовуватися як додатковий цементуючий матеріал.

Ключові слова: макулатурний скоп, золо-цлакові відходи, утилізація, сповільнюючі додатки, етрингіт. 